\title{
A cidade morria devagar Alguém que coopera, sua identidade incerta e o indeciso entre a ciência do direito e a consciência do justo
}

\author{
Guilherme Krueger
}

Resumen: Proponho-se a evidenciar o que a redução ao que é essencial numa cooperativa tem a nos dizer sobre a sua identidade. Em outras palavras, proponho-se a colocar os princípios universais de identidade das cooperativas emanada pela $\mathrm{ACl}$ entre parênteses, isto é, suspender provisoriamente para mim a crença de sua vigência, pois só assim posso acessar de modo intuitivo a identidade das cooperativas. Postula ainda que a intuição tem o poder de visar, através das particularidades das sociedades cooperativas organizadas e dos seus negócios, uma verdade essencial, que é comum a todas as cooperativas e acessível a qualquer um. Mas, o que é essa essência?

Palabras clave: cooperativas, princípios das cooperativas.

Abstract: The author focuses on revealing the identity and essence of cooperatives, ignoring the principles of identity which have arisen from and been set by the International Cooperative Alliance. In this work of fiction, the author approaches the subject supposing that cooperatives did not exist and uses intuitive methods to deduce the universal principles that are common guidelines for these types of organisations.

Key words: cooperatives, cooperative principles. 


\section{As indagações}

A resposta certa, não importa nada

O essencial é que as perguntas estejam certas

Mário Quintana

A significação do crédito cooperativo desde o amor inteligente de que fala a Encíclica Caritas in Veritate é partilhar um imaginário temporal para a cooperação. Este valor habita no imaginário e se articula com a juridicidade no direito. Para esse significado além da teologia, há o socorro das ideias de essência Edmund Husserl, valor em Max Scheler, maquinação em Martin Heidegger, da identidade narrativa em Paul Ricoeur, da hýbris na mitologia heróica, do totalmente outro em Emanuel Lévinas, e da desconstrução em Jacques Derrida numa integração possível do bom, belo e verdadeiro entre a ciência do direito e a arte literária.

O que identifica uma união de pessoas como cooperativa? Há várias respostas possíveis para essa pergunta. A maior parte delas vai aparecer como pacotinhos fechados. Como assim?! Quero dizer: aparecem a partir de uma definição ou várias definições que, por alguma(s) razão(ões), são postuladas como verdadeiras. Sobre essas definições, se exercita o raciocínio lógico analítico ou dedutivo para se demonstrar o que uma cooperativa é.

Via de regra, as definições vão se basear nos princípios de identidade da Aliança Cooperativa Internacional. Afinal, esses princípios são amplamente divulgados e aceitos. Outrossim, foram formalmente recepcionados pela Recomendação 193 da Organização Internacional do Trabalho, subscrito inclusive pelo Brasil. Portanto, esses princípios estão positivados em uma fonte formal de Direito Internacional Público.

Mas a principiologia da $\mathrm{ACl}$ sofreu revisões sucessivas. O que revela uma historicidade ao mesmo tempo em que remonta sua origem a um marco zero: a experiência de Rochdale. Ainda assim, é tentador, por isso mesmo recorrente, se recuar no tempo ao que se poderia chamar de protótipos de cooperativa. Nesse exercício, há quem recue até mesmo a eventos pré-históricos.

Essa tensão entre avanço e recuo históricos para forjar a identidade da cooperativa evidencia um problema que se situa na relação entre as experiências cooperativas concretas e «a» cooperativa, isto é, vista como um ser ideal. 
A questão é: se os princípios de identidade cooperativa evoluem no tempo e hoje já são variantes significativas dos originais, bem como o cooperativismo assume cada vez mais feições plurais, como ainda conseguimos intuir que uma cooperativa operadora de planos de saúde suplementar se identifica com a Sociedade dos Pioneiros de Rochdale, tanto quanto uma experiência comunal no interior de Moçambique se identifica com uma cooperativa agropecuária canadense que emite títulos no mercado e todas elas entre si? Afinal, o que há de realidade na identidade universal manifesta nos princípios da $\mathrm{ACI}$ ? Uma coisa fica clara na própria historicidade desses princípios e na sua tensão com os eventos cooperativos: a identidade permanente das cooperativas não é uma coisa; coisa é a positivação cambiante dessa identidade, emanada da $\mathrm{ACl}$; ainda que indubitavelmente entre ambas haja uma relação e uma dinâmica. Mas que relação e dinâmica são essas? É nesse ponto que percebemos não só a existência do pacotinho que mencionei acima, mas a possibilidade e a necessidade de o abrir.

Essa é a provocação inicial. Os princípios da $\mathrm{ACl}$ já são bastante conhecidos. Aliás, eles já dizem suficientemente acerca do que a cooperativa é para operadores face a alguma cooperativas.

No entanto tenho aqui a pretensão de levar a sério aquela velha brincadeira infantil de perguntar: que é o que é. Em outras palavras, num tom acadêmico, este artigo tem a identidade das cooperativas ao nível da ontologia por seu primeiro começo.

Proponho-me adotar uma atitude fenomenológica. Proponho-me a evidenciar o que a redução ao que é essencial numa cooperativa tem a nos dizer sobre a sua identidade. Em outras palavras, proponho-me a colocar os princípios universais de identidade das cooperativas emanada pela $\mathrm{ACl}$ entre parênteses, isto é, suspender provisoriamente para mim a crença de sua vigência, pois só assim posso acessar de modo intuitivo a identidade das cooperativas. Postulo ainda que a intuição tem o poder de visar, através das particularidades das sociedades cooperativas organizadas e dos seus negócios, uma verdade essencial, que é comum a todas as cooperativas e acessível a qualquer um.

Mas, o que é essa essência?

A essência da cooperativa é o que persistiria mesmo que todos os estatutos fossem apagados, todas as sociedades cooperativas fossem liquidadas e os seus sócios dispersos para sempre.

Digo então que a essência da cooperativa é a pura possibilidade de algo (uma união de pessoas) ser realizável como cooperativa. Aqui cabe uma pergunta: a intuição da essência se distingue da percepção do evento (algum modo de união de pessoas) ? Uma resposta com um espectro transcendental diz que essa intuição é a visão do sentido ideal 
que se doa ao evento materialmente percebido mediante nossas sensações. Ou seja, é a visão do sentido ideal que se doa ao que nos é dado pelo ambiente de cujo horizonte de indeterminação o evento percebido se destaca à consciência. E é nesse sentido que há a identificação do percebido como uma totalidade —uma cooperativa - ao que nos é dado pelo ambiente, que é sempre parcial e dependente de uma perspectiva.

Posso então afirmar que as circunstâncias finitas em que aparecem (se realizam) todas e quaisquer cooperativas, nas suas infinitas variações presentes, passadas e futuras, pouco importam às suas identidades como cooperativas.

Aqui cabe uma primeira advertência: cooperativa não é uma cebola. Os negócios e a sociedade não formam uma camada externa (visível) da cooperativa que possui camadas intermediárias, como a sua gestão, até um miolo sutil, que é a essência, a alma, o ânimo da cooperativa. Mas acessar a essência da cooperativa significa reduzí-la, isto é, eliminar dela o seu coeficiente de variação e imperfeição de toda a sociedade cooperativa e seus negócios. As sociedades cooperativas e seus negócios são dados no mundo. A essência é uma simplificação idealizada do que nos é dado pelo mundo. Mas a essência não é acessada por decomposição, quero dizer, essa simplificação não é obtida assim.

Isso me fala muito acerca do que é essencial: é aquilo que faz ser impossível a cooperativa ser outra coisa. Na essência, há um caráter de necessidade e invariância que se opõe à faticidade cambiante, combinada com fatores causais, consensual de toda união de pessoas. Ou seja, o que a cooperativa essencialmente foi antes também é o que a cooperativa essencialmente agora é, que também é e o que cooperativa pode essencialmente vir a ser. Pois cooperativa é tudo aquilo que nossa memória, nossa percepção e nossa imaginação puderem conceber. Mas tudo aquilo terá em comum o que não pode ser lembrado, percebido ou imaginado de outro modo sem deixar de ser cooperativa. Por isso, a essência da cooperativa é mais do que a sua identidade. Ele é o próprio ser da cooperativa.

Aqui cabe então uma então outra advertência: tudo o que foi dito até agora pode parecer pouco objetivo e isso é proposital. Porém, isso leva a se demonstrar que a identidade da cooperativa não é algum modo de representação ou projeção mental de algo material —a sociedade e os negócios que lhe realizam-. Tampouco é relativo a circunstâncias históricas e culturais, mero resultado de um consenso arbitrário ou discricionário (efeito exclusivo de um juízo de conveniência e oportunidade), ou de um discurso ou especulação metafísica, ou mesmo de um dogma. ISSN: 1134 - 993X, Núm. 46/2012, Bilbao, págs. 107-131 
A identidade é a cooperativa diante da experiência sensível (a união de pessoas), muito embora apareça através desta, naquilo que é mais do que uma coincidência dentre fatos, ou uma deliberação por potências volitivas, ou uma opinião de autoridade, mas uma possibilidade necessária para intuí-la no âmbito das hipóteses.

Enfim, através da experiência sensível (negócios e sociedades) de um modo de união de pessoas, posso intuir a essência da cooperativa. Mas essa essência diz das possibilidades (realidades hipotéticas, pensadas) dessa união, e não só das suas realidades concretas (sensíveis). Por isso, é possível acessar o que é (o que é) cooperativa de antemão ao conhecimento de um evento cooperativo específico, ou mesmo de um número significativo de eventos e até de todas as cooperativas no mundo. Os eventos cooperativos, como variações efetivas, se mostram então como indutores para o exercício da imaginação, ou melhor, da variação imaginária.

Eu posso dizer isso com outras palavras: a experiência dos fatos (realidades sensíveis), isto é as sociedades e negócios da cooperativa, me diz sempre sobre ela, mas não dela. O exercício do pensamento acerca dos limites das possibilidades de cooperativa, isto é, o exercício disciplinado e rigoroso da intuição, memória e imaginação (redução fenomenológica) é o que diz da cooperativa mesma.

O que identifica todas as cooperativas no mundo é uma descrição idealizada, reduzida (mas não decomposta), constante, invariante e totalizante delas. Por quaisquer que sejam os lugares e as épocas em que se falou, fala e falará em cooperativas (e até mesmo quando delas não se falar), por numerosas sejam as sociedades e os negócios aos quais se atribui a identidade de cooperativa no mundo, mesmo que haja muitas cooperativas mal geridas e em desvio de finalidade, ainda que ela seja exilada na utopia, é sempre de cooperativas que se trata.

Também cabe mais uma advertência: ao contrário do que parece, a atemporalidade e a constância da essência não significa que ela seja estática. Há uma dinâmica. E essa foi a grande contribuição da fenomenologia de Edmund Husserl. A essência não «habita» no meu «eu», nem nas sociedades e os seus negócios. Nem em um terceiro lugar hipotético, como imaginava Platão. A essência só existe num movimento que acontece o tempo todo e em todo o lugar: no direcionamento de minha e sua atenção (intencionalidade) a algo que neste ato se destaca do mundo para elas como um objeto dado e neste ato doa intuitivamente um sentido a ele. A fenomenologia transcendental se apresenta como um modo de se compreender o dinamismo pelo qual a consciência dá sentido aos objetos do mundo, inclusive as cooperativas. É esta a idéia que culmina com a compreensão da existência e da historicidade 
do cooperativismo. Pois a essência é uma sempre uma síntese de todos esses sentidos descritos.

Entre essa descrição e a suas manifestações fáticas (negócios e sociedades) não há uma relação dedutiva, comparativa ou de causalidade. Essas relações se dão entre coisas (fatos), mas não entre coisas e essências.

Não podemos pensar sobre a cooperativa, sem que tenhamos pensado nela. Se quero dar um sentido aos fatos das cooperativas, tenho de fundar esse sentido na essência das cooperativas. Por isso, o domínio sobre os fatos, isto é, seu estudo, controle e manipulação, ainda que metódica e rigorosa, nas mais diferentes disciplinas científicas, como a administração, a economia, o direito, contabilidade, não dá qualquer significado para a cooperativa. Esse significado é dado de outro modo completamente diferente.

Também cabe aqui outra advertência: isso tudo o que foi dito até agora não quer dizer que haja uma independência entre fatos, as sociedades cooperativas e seus negócios, e a essência da cooperativa. É necessário que eu não caia na armadilha do idealismo ao exercitar a redução fenomenológica. Não posso supor que eu seja uma consciência desencarnada que paira por cima e por fora da minha experiência concreta (sensível) com as sociedades cooperativas e seus negócios. Não terei uma ideia rigorosa de cooperativa olhando para o céu azul. Os dados e suas estruturas formais extraídos dessas sociedades e seus negócios pelas ciências dos fatos é o que me é dado primeiro pela existência. Esses dados são o que me remetem, mas não me resolvem duas questões que são precedentes e radicais: a posição que essas ciências assumem perante a cooperativa e a idéia que faço do que é real e objetivo na cooperativa. Isto é, o que identifico rigorosamente como cooperativa nas sociedades e negócios que conheço e opero.

Enfim, o Direito, a Administração, a Sociologia, a Contabilidade etc contribuem, sem dúvida alguma contribuem para o esclarecimento acerca da identidade das cooperativas, mas nenhuma delas, como ciências dos fatos ou positivas, que são, e também todas as técnicas delas decorrentes para o domínio das cooperativas, me prestam suficientemente para definí-las como cooperativa. Para definir a identidade das cooperativas, não basta que eu acumule conhecimento que me explique os fatos acerca da cooperativa, pois ela não é acessada por uma soma de seus resultados. É necessária uma atitude compreensiva. E compreensão não se deduz simplesmente de uma explicação.

A objetivação científica tão-somente concorre para superar os limites de minha intencionalidade e que são impostos pelo corpo que me encarna. Ela evita que, para dar sentido à cooperativa, eu me 
torne dependente exclusivamente de uma compreensão imediata e situada. Mas, isso não diz tudo da cooperativa. É necessário acessar a dimensão subjetiva das sociedades cooperativas e seus negócios que os torna fatos humanos. É para o acesso a essa essência radicalmente humana que a fenomenologia apresenta um modo de compreensão.

Os dados explicados pelas ciências dos fatos (positivas) e as técnicas que os dominam não são substitutos da compreensão, mas se erigem como massa crítica de conhecimento para uma compreensão intersubjetiva. Pois, compreender é um encontro de sentidos, isto é, aquele que compreende dá um sentido à cooperativa que é, em síntese, o mesmo sentido doado por aqueles que se unem em sociedades cooperativas e com ela realizam negócios, ou seja, aqueles que de certo modo animam o objeto a ser compreendido. Compreender as sociedades cooperativas e seus negócios é percebê-lo "por dentro», e não acerca dele. Isto é, compreender é encontrar a existência da cooperativa no mundo da vida.

No plano da existência, a consciência é como uma luz lançada constantemente em direção ao mundo (intencionalidade proposta por Husserl). O mundo é tanto como o que fomos e somos, algo solidificado, absoluto e definitivo, quanto o que seremos. A consciência desliza sobre o que fomos e somos, mas nenhuma constituição realiza aí, porque isto já foi dado. Mas, isso nada importa diante das possibilidades que ilumina (sentidos) na busca do que seremos. A consciência, como intencionalidade, interage com as sociedades cooperativas e seus negócios ao constituir o vir a ser cooperativa e nisso reside a chave da adequação hermenêutica no Direito Cooperativo. Esse modo de pensar eleva a liberdade como potência da realidade. Existir significa ultrapassar constantemente o ser «cooperativa», em si, que já está determinado, numa aventura de constituir o porvir.

Há uma crença generalizada e razoavelmente fundada de que os Princípios Universais de Identidade das Cooperativas, emanados da $\mathrm{ACl}$, expressam bem e positivam essa síntese. Mas ao fazê-los, a ACl condiciona igualmente essa positivação ao contexto histórico-espacial em que se vivencia as experiências atuais de cooperativas em escala mundial, trazidos à descrição, análise e comparação no seu âmbito, onde se guarda uma alentada memória do cooperativismo e que também se constitui como um foro privilegiado de debate e reflexão, acordos e dissensos acerca do que pode vir a ser cooperativa no futuro e em oportunidades do presente.

Aqui se permite então o "truque» com que o operador das cooperativas, normalmente hábil em lidar com os fatos das cooperativas 
—uniões de pessoas e seus negócios - se desvia do problema de lidar com a essência das cooperativas: nos princípios universais de identidade cooperativa, emanados da $\mathrm{ACl}$, há uma faticidade com que ele pode dominar tecnicamente a identificação das sociedades e negócios das cooperativas. Mas ao fazê-lo deve admitir que seu acesso é a uma identidade turva, ou seja, contextualizada.

Essa falta de clareza se evidencia na tensão entre essa faticidade dos princípios (sua positivação em enunciados lógico gramaticais aprovados por resolução assemblear) e sua validade, ou seja, a sua capacidade de dar conta de todos os sentidos possíveis para a cooperativa, na medida em que vão afetando a síntese que se apresenta como essência.

Dito tudo isso, você já deve estar curioso: afinal, o que identifica uma cooperativa? O que é a essência da cooperativa? Que é (o que é) a cooperativa?

Certamente a descrição idealizada, reduzida, constante, invariante e totalizante da cooperativa tem por eixo a cooperação.

Posso aplicar essa noção numa reflexão sobre o adequado tratamento tributário ao ato cooperativo. Partindo da premissa que a cooperativa e o ato cooperativo são manifestações da cooperação na ordem econômica, cheguei, com o socorro dos estudos de, a três vetores teleológicos da cooperação, quando ali se manifesta:

- A democracia como valor intrínseco à atividade econômica;

- Geração de riqueza vinculada ao desenvolvimento local;

- Eficácia em ambientes de escassez de capital e em mercados imperfeitos.

Não importa tanto o que as cooperativas foram, são e podem vir a ser, mas elas são sempre: uma cooperação entre seus sócios. Uma cooperação com a qual necessariamente exercitarão a democracia em sua gestão, gerarão riqueza que circulará necessariamente na comunidade local onde está estabelecida e resolverão ou minimizarão ao menos os seus problemas comuns com a imperfeição de mercados e com a escassez de capital. Sem isso, não há como pensar uma possibilidade realizável como uma cooperativa. Isto é, me é impossível pensar cooperativa de outro modo: não há como suprimir a cooperação sem destruir a cooperativa como um objeto.

Quanto a esse caráter de cooperação, Marco Aurélio Greco logra situá-lo dentro do ordenamento jurídico, no caso, a Constituição Federal, e leciona que «a cooperação tanto surge como um desdobramento do objetivo de construir uma sociedade solidária (art. $\left.3^{\circ}{ }^{\circ}, 1\right)$, como princípio da ação internacional (art. 4. $\left.{ }^{\circ}, I X\right)$, como instrumento da atuação 
das entidades públicas, umas em relação às outras (art. 23, parágrafo único), ou em relação à população (art. 43, \& 3. $\left.{ }^{\circ}\right)$ ). Como se pode perceber, a Constituição Federal de 1988 impôs a ultrapassagem de um modelo teórico constitucional para a estruturação do poder entre o Estado e a Sociedade para um modelo de cooperação entre Sociedade e Estado para a concreção de uma noção ideal de Justiça.

A Constituição Federal, mais do que o cume hierárquico de um conjunto legislativo, é um plexo de normas e valores fundamentais. Dentre as normas encontradas na Constituição, há regras, que são mandatos categóricos sob critérios cronológicos, hierárquicos ou de especialidade; e há princípios, que são mandatos de ponderação e otimização dos valores. Os valores são, por sua vez, fundamentos éticos, que se manifestam como pólos da ordem constitucional, com os quais o fazer Direito não passa pela indiferença diante do mundo da vida.

Normas nunca são absolutas, por mais que positivem um imperativo: a concreção demanda a descoberta de novos sentidos que refundam sempre que necessário o que cada norma é - dinâmica imprescindível para a validação da norma ante a sua existência fática. A invariância no Direito diz dos valores, e não das normas.

O que se pode depreender é que a cooperação assume, como visto, um valor essencial (necessário, possível, absoluto, invariante, atemporal e universal) para a Constituição, sendo que a cooperativa vai manifestar essa essência na ordem econômica.

Contudo, tem sido muito comum os cooperativistas recorrerem a uma ética formal. Trata-se de um pressuposto ético regido pela relação racional entre meios e fins. Essa ética não dá conta da carga primitivamente emotiva que polariza a decisão de constituir uma cooperativa. É pertinente notar que padres costumam estar mais envolvidos do que economistas e advogados na mobilização de comunidades para a criação de cooperativas que são bem-sucedidas.

Uma questão que foge à ética formal é como reconstituir essa escolha original, quase mítica, em que ser sócio de cooperativa é algo que remete, de alguma forma, a uma devoção de vida e uma vocação, ambas dirigidas ao proveito comum. E não simplesmente algo resultante de contas cambiantes de vantagens e ônus, incentivos e sanções disciplinares, custos e margens. E, mais importante, que ambos os sentidos não são excludentes, mas complementares.

Para dar materialidade à ética, e com isso, evidenciar a cooperação numa escolha que constitui a cooperativa em sua originalidade, é preciso primeiro admitir o postulado de que a qualidade dos bens, as aspirações ou a necessidade não fundam os valores, mas são valores que 
dão aos bens qualidades, orientam as aspirações e dão sentido às preferências face às necessidades sentidas.

A visada que se abre para uma ética material é o das preferências, manifestações irredutíveis a um exercício de pura racionalidade, pois elas só são acessadas pela afetividade, a ordem do coração desconhecida da razão, na expressão poética de PAsCAL.

Dito em outras palavras, a questão dos valores que qualifica uma sociedade como cooperativa e que constitui sua adequação é, depois de mais nada, um reaprendizado em ver o ato constitutivo de uma relação jurídica societária cooperativa como um ato de preferência.

A materialização da ética pelo sentimento permite revelar o que de essencialmente válido existe na cooperativa que funda as normas positivadas na Constituição Federal voltadas a ela.

Se for verdade que os valores transcendem a afetividade, eles só aparecem na medida em que a eles se voltam os sentimentos. Outrossim, precisam ser refletidos numa análise transcendental, ou seja, numa tomada de consciência de si como alguém que sente, dos valores que visam e da hierarquia axiológica que sintetizam.

Mas, essa consciência imediata do bem do ato que é cooperativo nem sempre se realiza no cotidiano dos negócios das cooperativas, pois as escolhas ocorrem num emaranhado de símbolos, pensamentos, informações, discursos, desejos, as circunstâncias e os conflitos de um eu descentralizado (um eu, enquanto conjunto coerente e consciente de crenças e desejos, que convive com quase eus, ou seja, conjuntos alternativos e inconscientes de crenças e desejos). Por isso, é necessário o recurso a enunciados lógico-formais do dever-ser e as prescrições como referências para o discernimento da moral em sua historicidade.

Em que pese a utilidade do recurso, e até por sua contingência, não se pode prescindir de voltar para os valores, em seus absolutos e para a hierarquia axiológica que se insinuam além dos homens, que variam de sensibilidade, seja individualmente, seja coletivamente. Só então se poderá salvaguardar a cooperação, sendo garantida também a existência das cooperativas como uma possibilidade.

Não se pode escapar desse esforço filosófico voltado para a materialidade da cooperação, sem o qual qualquer adequação de tratamento científico está condenada a perder sentido no trânsito de uma solução contingente, um ajuste de contas comparável à pedra de Sísifo, de nada adiantando para o livramento de sua pena a sua mitológica maestria em aproveitar oportunidades.

Para a entrega, irei dar uma guinada. Doravante, a fenomenologia não será mais abordada a partir da transcendentalidade, isto é, como 
visão, tal como a formularam Husserl e Scheller. Mas a partir da hermenêutica, como texto de ser, como propõem Heidegger, Lévinas, Derrida e Ricoeur.

Antes da iniciação, não-tempo. Início parte do abraço dos titãs Urano e Gea para a descoberta da alteridade. Fértil, Gea trai Urano entregando uma foice a um filho, Kronos, este totalmente outro. Ele castra Urano, liberando Gea do abraço. Do sangue derramado, surge a memória, as Eríneas.

Mas, Kronos devora os próprios filhos gerados por Reia, sua irmã. Reia, fértil, por sua vez, trai com um ardil. Esconde um filho seu, Zeus. E Zeus logra o vômito de Kronos, trazendo de volta seus irmãos à narrativa. Liderados por ele face aos titãs, inicia-se a mãe de todas as bataIhas: a destinação como sucessão na narrativa.

O abraço de Urano e Gea é a solidão de dois que se explicita no exílio de seus filhos fora da narrativa. Tempo é a traição criativa do outro à (e na) tradição: tempo já é tradição, entrega, como espectro disjunto que se destina à injunção pensável, mas que se mostra aí tanto quanto já se oculta.

Kronos é a positivação primeva da alteridade, ainda negativa na solidão de Urano e Gea. E também é o tempo que nega a si como sucessão. Pois Kronos, ao castrar seu pai em desprezo à própria tradição, recusa da herança transmitida. Há compulsão, suspensão, repetição, e não há destinação. A instauração do governo do mundo pelos deuses olímpicos -imortais, mas já criados na narrativa liberada da suspensão é a historicidade que já se mostra no horizonte da narrativa- Na narrativa, os deuses olímpicos já se mostram destinados ao governo do mundo.

Ainda há que se instaurar, na mortalidade como destinação, o sentido trágico da existência: a medida no tempo que se mostra na própria transgressão pela desmedida —a tensão entre a hybris e o métron- que é a polarização nas escolhas, que não pode tender à neutralidade descritiva e analítica sem ocultar do acontecimento ético mais do que dele revelar. A humanidade, sua proximidade e sua assimetria face à divindade ainda precisa aparecer na narrativa. Mas isso é outra estória. Interessa antes aqui dizer do necessário na técnica. 


\section{II}

Nossa percepção ancestral de um tempo mensurável vem dos ciclos, uma subsistência: dia e noite, luas cheia e nova, chuvas e seca, equinócio e solstício, preamar e baixamar, floração e frutificação, gravidez e menstruação. Outra percepção ancestral de um tempo mensurável emerge da necessidade de se marcar momentos como evidências de sobrevivência, passagem e renovação —insistência-. Na confluência dessas duas percepções, há a integridade de fenômenos culturais.

Do que não é para o que é, pode haver vários momentos. A técnica é o domínio sobre esses momentos, na medida em que possui uma leitura do ser desses momentos como estágios de um processo.

Porém, ao contrário do que pode insinuar um pensamento descuidado da tradição, a necessidade da técnica não está na sua instrumentalidade prática, isto é, na atividade voltada à consecução de um fim. Embora haja muita serventia para este pensamento, certeza e verdade se unem, mas não se confundem. Pois, para assumir uma afirmação como certa, é necessário que alguma afirmação já tenha se mostrado, antes, verdadeira. Assim, o verdadeiro, antes de ser correto, se faz (poiesis) - já é o desvelamento-: o mostrar aquilo que é vigente como sua destinação, consumação.

Com o apego desmedido (hybris) à instrumentalidade da técnica, há uma mudança do seu modo de ser, com a incorporação desse seu próprio logos em si —a tecnologia—: um repertório de medidas para fazer o que já está proposto desde antes. Portanto, a tecnologia deriva da ambigüidade na physis: a normalidade do fazer e a norma do fazer. E a tecnologia é uma evidência da maquinação.

A maquinação só foi possível com a articulação da técnica com a autonomia do eu. O sujeito transcendental se mostra como vontade de objetivação. Toda realidade é objetivada para uma relação agentepaciente e o fazer se mostra como intervenção de um sujeito já constituído que impõe o seu querer, que se mostra como a estrutura da realidade por categorizações. O pensar se mostra como operação de categorias e as categorias como um domínio da realidade pelo eu. Então, a realidade objetivada é o domínio sobre a realidade e de si própria pela subjetividade. Pois o sujeito se certifica de si para aparecer o objeto. O sujeito, em tudo que quer, precisa antes querer a si mesmo. O aparecimento do objeto é a certeza de si em sua queda no eu. Então, o sujeito aparece como um realizador de atos e como a causa do fazer, sem a sua afetação pelo fazer. A maquinação aparece quando a realidade assim constituída passa a ser vista como natural e óbvia. A maquinação é a radicalização da estrutura (um ente que governa o de- 
vir) da objetividade, quando o sujeito se dilui na transubjetividade: um objeto para o próprio do homem - o espírito- como queda da última dimensão selvagem da personalidade. A maquinação é dominação da própria subjetividade: uma autonomia da estrutura de produção de metas.

Com a palavra maquinação, posso apresentar uma trajetória reinterpretada da tradição, na qual denuncio a culminância de um momento histórico que se esgota na contemporaneidade. Denuncio não exatamente o deixar de lado a indagação em prol da ação, isto é, o esquecimento de se perguntar pelo que é o que se apresenta a nós no mundo para se focar na manipulação desse dado em função do que se quer. Denuncio o esquecimento desse esquecimento: o que as coisas são deixando de ser um mistério, um principiar. O que as coisas são passando a ter respostas sem perguntas, sempre determinadas pelos fins pragmáticos ou sistemáticos a que são submetidas, isto é, pelo que se quer delas. Com esse esquecimento do esquecimento, o ser humano se deixa encarcerar em sua própria constituição como objeto natural —um animal, ainda que racional-: um ser entre outros seres no mundo, e assim também submetido à sua própria vontade de poder. É a prisão em seus próprios projetos, vistos como sonhos; em seus cálculos, vistos como realidade decifrada.

As essências (eidos) não são nada mais que os eternos enigmas que nos apresenta este mundo tal qual é nossa vida nele. No representar, no pensar, na imaginação, na fantasia, o essencial não se esgota no ser objeto para a consciência. Brancura, nobreza, feiúra, utilidade. Tudo isso está presente. Oferecem-se coisas que se nos fazem irresistíveis. Como podemos viver um só minuto a mais sem os ter? Sentamonos numa Igreja silenciosa e um Cristo ensangüentado se nos destaca. Nós não nos mexemos. Muito menos Ele. Nem de nós, ou da imagem emana um éter, uma energia sutil, uma força magnética. Mesmo assim, um toque pode ocorrer. Esta possibilidade existe.

De que se trata? O que torna possível uma organização de fatos acontecer como um discurso? Nossas memórias, uma narrativa? É o encanto que teima subsistir, sem o qual os homens não penam, nem se convencem de que a própria existência vale a pena. É um enigma insistente e resistente ao cumprimento da promessa de desencanto do mundo.

Os valores atravessam a humanidade. Intuímos que essa singularidade faz da definição de nós como animais, ainda que racionais, apenas uma meia-verdade: em que pesem todas as tentativas de sua racionalização, os valores não se mostram em desencanto. Azedume: elementos químicos, papilas gustativas e impulsos neurológi- 
cos. Pois então, um namoro não pode azedar ? Não há quem diga que não.

Em todo caso, há «algo» comum a todos os valores que se apresenta como uma pretensão de ser. É uma remissão à questão ontológica do valor. A percepção e a qualidade evidenciam o aparecer do valor como algo, ainda que sempre apareça para alguém em outro algo ou alguém. O valor então é um ideal que não se manifesta só no sujeito, nem se identifica inteiramente com um objeto. Mas, uma questão emergente é a impossibilidade de se reduzir o valor, ele próprio, a uma condição de objeto do conhecimento.

Dessa evidência, na medida em que é para as pessoas que os valores se mostram, emerge a impossibilidade de se reduzir o ser humano a objeto para um outro ser humano. Isto é, a relação do ser humano com o seu par não pode ser inteiramente regida pelas leis do conhecimento objetivo: há pessoas.

Nessa intersubjetividade, manifestam-se a compreensão e a comunhão, cujas existências permitem supor os valores como existentes além das respectivas personalidades e dos objetos a que se voltam suas intenções. Haver pessoa remete imediatamente a valores, mas também à valoração do outro, que me escapa. Estabelece-se entre as personalidades um aparecimento de «algo» dos valores que encontra uma possibilidade de dever-ser.

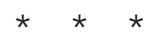

\section{I}

Prometeu e Epimeteu eram titãs, gigantes numa época em que, no mundo, os animais ainda não existiam. Pois foram eles que os criaram. Não satisfeitos, quiseram criar uma raça ainda mais nobre, capaz de admirar as estrelas. Pensaram-no de pé e cujo rosto se erguia ao céu.

Tendo empregado com excelência todas as habilidades e qualidades diferentes que imaginaram para os animais criados, tiveram dificuldade em dar ao homem algo especial. Então, Prometeu teve uma idéia. Pediu ajuda a Palas Athena, a mais sábia das deusas. E assim subiu ao céu, acendeu uma tocha no carro do Sol e a deu ao homem.

Zeus alarmou-se com a ousadia de Prometeu e com o poder na posse do homem. Com esse poder, com o qual ensaiava o domínio da natureza e iniciou a civilização, temia Zeus que o homem usurpasse a soberania sobre o mundo, como ele e a primeira geração de 
deuses olímpicos haviam conquistado dos titãs. Então, arquitetou um plano.

Ele moldou outro ser, em tudo semelhante ao homem. E determinou que cada deus do Olimpo the desse um dom. Assim, Ihe foram dadas a beleza, a graça, a persuasão, as artes... mas, eis o ardil: no dote veio a curiosidade e a perfídia. Criada a mulher, foi chamada Pandora. Pandora foi dada como presente a Epimeteu juntamente com uma caixa. Porém, a caixa vinha com uma advertência: jamais poderia ser aberta. Foi o suficiente para que ela não mais sossegasse. Um dia, aproveitando-se da distração de Epimeteu, Pandora finalmente abriu a caixa. Dela, saíram todos os males que assolam o homem. Pandora, ao ver o que fez, apressou-se a fechar a caixa, mas só conseguiu não perder o que havia no fundo dela: a esperança.

Passaram-se as eras e então, um dia, enquanto os deuses no Olimpo banqueteavam, Eris, a deusa da discórdia, ofereceu uma maçã de ouro àquela que fosse a mais bela. Hera, a mais maternal das deusas, Palas Athena e Afrodite, a mais sensual, resplandeceram. Claro, nenhum outro deus quis se meter nessa saia justa. Então, para a tarefa de indicar a quem pertenceria o pomo da discórdia, foi escolhido um belo mancebo, Páris, príncipe de Troia. Embora príncipe, ele vivia como pastor distante da terra natal. Pois, quando nasceu, uma profecia foi proferida: com ele, Tróia seria destruída.

Levado ao Olimpo, nenhuma das três deusas confiou no seu julgamento imparcial. Hera ofereceu-lhe glória. Palas Athena, poder. E Afrodite, a sedução. Páris, ele próprio ofuscado pelas ofertas, escolheu a merecedora do premio. Afrodite então o levou a Esparta, onde Páris conheceu a rainha Helena, esposa de Menelau. Helena, claro, apaixonou-se perdidamente por Páris e com ele fugiu para Tróia, uma cidade inexpugnável.

O que Páris não sabia (Tróia era uma cidade asiática) é que o pai adotivo de Helena, Tíndaro, rei de Esparta, quando ela atingira a puberdade, temendo que a inveja de sua notável beleza (era a mais bela das mortais) destruísse a sua cidade, havia articulado uma aliança entre todos os príncipes gregos. Assim, todos, já aliados entre si, temeriam desafiar aquele que Helena escolhesse para marido, pois sempre haveria o risco de enfrentar os demais.

Por conta disso, Menelau, já tendo sucedido Tíndaro, e seu irmão Agamenon, que reinava sobre Micenas, puderam reunir o mais poderoso exército jamais testemunhado antes pela humanidade. Começava assim a mãe de todas as guerras. 


\section{II}

Toda explicação fica pela metade, pois o homem não consegue terminá-la. O olho não se farta de ver, nem o ouvido se farta de ouvir. O que aconteceu, de novo acontecerá; e o que se fez, de novo será feito: não há nada de novo sob o sol. (Ecl 1:8-9)

\section{III}

A atividade reflexiva manifesta em nós uma distinção em relação a nós mesmos, ao outro e ao mundo e nos revela a nossa condição pessoal. Se as pessoas convivem com elas próprias, quem elas são se vela e se desvela como que numa casa de espelhos. Nesta atividade reflexiva, pensamentos e acontecimentos se sucedem até que se vislumbra uma identidade, que só aparece numa narrativa que é figuração da vida.

Posso dizer de outro modo. Conhece-te a ti mesmo, epígrafe no portal do oráculo de Delfos, tem a ver obviamente com a pregunta «quem sou eu?». Mas, quando procuro responder este questionamento, percebo o que é meu: corpo, consciência, intenções, experiências, desejos, sentimentos, escolhas, projetos, patrimônio, psique, espírito, alma, tradição, código de DNA, sexo, liberdade, biografia, virtudes e vícios... Mas, desde que seja meu, há um quê de diversidade em relação ao eu. De modo que o eu fixa um nada a dizer (não-tempo) que torna possível o que é dito.

Há uma experiência sensorial muito simples que mostra isso. Esfregar as mãos. Quando esfregamos as mãos, não podemos distinguir a mão que toca e a mão que é tocada. Não podemos responder que somos quem toca para sermos quem é tocado, ou que somos quem é tocado para sermos quem toca. Quem somos só aparece integralmente na narrativa da ação de esfregar as mãos: «Eu esfrego as mãos.»

Em todo caso, nenhum objeto ou ação pode fixar a identidade de alguém, senão como apropriação de si mesmo. Há um lançamento, uma vertigem, no instante já que funda a experiência de si mesmo como um outro.

A condição de alguém que narra sua vida é ser em sincronia o autor e o intérprete de si mesmo. Então, poder-se-á afirmar que possivelmente o eu é de uma integridade não transparente, aproximando-o de um ato de criação análogo à ficção. O eu se faz. O eu pode ser um autoposicionamento mais literário do que literal e, em grande medida, o eu já é um ato de navegação por símbolos da cultura. 
Persona é originalmente máscara, algo que se veste, mas algo que se estampa (adere ao) no rosto e se dá já como um sentido narrativo a ele. Ambígua, essa máscara é a personalidade que remete tanto ao personagem como à pessoa desde um tempo em que sequer na pessoa se pensava. Pensar a personalidade antes mesmo do eu (cogito autônomo constitutivo do sujeito diante da matéria, da forma e do ideal) faz verdadeira a compreensão de (ser tomado por) uma estória como sendo, de certo modo, um testemunho. Assim como um testemunho é sempre uma estória desvelada e compartilhada.

Há o encontro de verdades insuspeitas na encruzilhada do acontecimento, o horizonte no interior do qual há o encontro entre o literal e o literário. Uma delas é a hybris.

Nas tragédias gregas, a hybris é a desmedida do herói em suas peripécias. Essa desmedida conduz ao clímax: a queda e à sujeição a que está destinado o herói em sua mortalidade. No herói grego, visado a partir da tradição cristã, a ausência de contenção em si, de ascese no próprio acontecimento, pode facilmente ser apropriada como algum pecado capital, enfim, como um mal que o perde. Mas, a personalidade é um convite a seguir os rastros da ambiguidade, da hybris no imaginário mítico.

O herói é um semi-deus. Um ser híbrido, úmido, ambivalente. Capaz de feitos extraordinários, está destinado à transitoriedade existencial. Da proximidade com os deuses emerge um poder que the deixa desinibido à transgressão, à incontinência, ao insulto, ao excesso ofensivo, ao perjúrio, à traição, à imprudência, à injuria. O herói manifesta a hybris quando a narrativa oscila entre gestos de coragem ou habilidades extremas e desejos incontidos ou insolentes, redundando em violência, morte, sofrimento, cegueira e opressão. Mas, também na criação de possibilidades, de realidades e desfechos dramáticos. Enfim, a hybris aponta para a criação de situações de perigo pela demasia. Mas, mesmo assim, uma faculdade da condição humana.

A hybris é a revelação de uma intimidade assimétrica entre o herói e a divindade. Intimidade esta fadada à exposição do métron pela extrapolação, os limites e imposições contextuais com os quais a hybris estabelece uma dialética em sincronia ao deslocamento e ao perigo na narrativa.

A hybris é a evidencia da co-criação a que está fadada a personalidade em sua ambigüidade. É essa ambigüidade que expõe diferentes possibilidades do devir na narrativa. Próximo da divindade, o herói é livre no interior do horizonte de seu destino. Próximo, mas que com o divino não se confunde, pois divindade é a ausência de destino trágico para si. Assim sendo, essa liberdade Ihe é incontrolável em sua própria 
situação histórica, isto é, na ausência de onipotência positivada no destino.

É perceptível que a ética apresentada a partir de elementos exteriores a si mesmos oscila entre a humanidade como recepção de estímulos externos como um mosaico que precisa ser ordenado para formar razões sistemáticas e como atividade de inspeção intelectual do mundo. De certo modo, a ética assim é retirada da promiscuidade, da ambiguidade das vivências que se dão para tornar-se inteligível, isto é, um pensamento de certo pensar, isto é, uma linguagem para o real como descrição que com o próprio real se confunde. Ordenando a vivência pelo conceito, a ética confunde o sentir e o sentido. Não se dá a compreensão da vivência, mas uma vivência compreendida a partir de um discurso sobre ela.

Para um pensamento capturado pela teoria que critica e esclarece um comportamento como justo entre relações pessoais e patrimoniais, por exemplo, essas definições instauram uma ordem cognitiva para a ética. Há aqui um postulado de que a verdade é a adequação do juízo à coisa, conquanto objeto de conhecimento.

Conquanto a compreensão fértil e transgressora possa suscitar uma comunhão em que, em relação ao matrimônio e ao amor, não há nada de novo sob o sol, a dialética entre pessoa e patrimônio traz para a ética a historicidade já como ideias de linha, processo, progresso e superação. Não há nada de errado nisso. Mas, tento pensar essa linha como o fio de Ariadne. Se, com esse fio, nos conduzimos em domínio (injunção) do que foi antes e será depois disjunto (desafio), o esquecimento do labirinto onde mora esse desafio esvazia o desvendamento do vigente para outras possibilidades ao se mostrar como ocultação do que não pode ser decidido por reduções a fios.

Não ter nada de errado não esgota as possibilidades do justo, nem do verdadeiro, numa relação em que se dá a ética. Pensar linha, processo, progresso e superação é pensar em causas. E causas são respostas ao dever vigente. As causas respondem por aquilo na qual uma justiça é possível. Como modo de resposta e dever, a causa produz uma justiça histórica posta adiante. É nessa decisão entre pessoa e patrimônio que se produz justiça como seu desvelamento dialógico posto por fora do próprio acontecimento a que se faz uma justiça possível.

O problema está na pretensão de totalidade. A ética, totalmente resolvida a partir das ideias de pessoa e do patrimônio como exterioridades entre si, reduz-se a uma moral que se esgota em uma operação técnica que é boa ou ruim, se funciona ou não num determinado contexto. Se tal redução pode produzir algumas certezas com que se pode 
operar, dificilmente ela responde por ajustes ao que já é certo. Então, é preciso encontrar erros no comportamento, custe o que custar. Mas, eis o problema de toda positivação moral: o mal se insinua nos ânimos, mas se oculta entre as razões e as vontades

Confesso meu fascínio por talvez outra atitude filosófica que enfraquece a justiça como uma idéia de patrimônio cultural, mas que se abre ao momento de originalidade de uma vivência sua; momento este em que se relacionam o possível e o ausente. A experiência, neste sentido, é ambígua: tanto uma falta, um vazio que faz necessária uma presença, como um excesso que demanda nova expressão sobre um mundo que já foi expresso.

Trata-se não de uma superação da dialética entre pessoa e patrimônio, mas o seu enfraquecimento como produção de novos direitos ou novos valores, eis que umedecido na própria ambiguidade que diz mais dos ajustamentos do que de certezas.

Em Verdade e Conjetura, Miguel Reale notou: «o valor é um ente autônomo, por ser-lhe inerente um sentido vetorial de dever-ser, em razão do qual se põem os fins, os quais podem ser vistos como vestes racionais do valor».

O Direito então nos veste. Se nos veste, nos lembra de nossa nudez.

Há aqueles que, como Miguel, sabem disso. E, de um modo ou de outro, perguntam: «e daí? Nascemos nus. Nudez é liberdade».

O que me intriga é que a nudez humana recorrentemente evoca a antropofagia. É que na nudez nossa, não aparecem apenas as tentações do corpo, na forja do sangue, ossos, músculos e hormônios e no torno da psique. Mas, também a boca - a profundeza da alma, o abismo que é a humanidade do homem.

As tentações, concordo, não são nem boas, nem más em si mesmas. Mas o que acontece por esta boca aberta às tentações? Aí, a polarização delas entre o bem e o mal. Da boca escancarada, e só dela, é possível que saia todo o mal.

É isso que faz da nudez algo assustador. Por menos vestido que foi o tupiniquim, ainda ele se vestia de ritos de passagem. Porque a nudez só se faz presente pelo olhar sem complacência que nos é lançado por quem nos conhece tão profundamente que é capaz de gritar, aterrorizado, o quão nus estamos. E grita porque, quando somos vistos nessa nudez absoluta, ela é insuportável à convivência, pois mostra o que há de perverso em nós.

Quando isso acontece, só nos resta trocar de vestido. E aí está todo o sentido poético na historicidade da norma jurídica. 
No Direito, o justo e o certo podem assumir uma pretensão de superposição e uma pretensão de verdade. Mas, o certo e o justo, no Direito, se mostram também numa correlação em aberto.

Clarice Niskier é atriz. Num programa televisivo de entrevistas ao vivo, ela se declarou uma judia budista. Uma espectadora manifestouse: «Ora, ou bem se é judia, ou bem se é budista». Clarice desarvorouse ante a severidade da crítica à sua convicção. Mas, foi socorrida pelo rabino Milton Bonder, ali também convidado: «uma contradição é em termos». A hospitalidade de Bonder moveu Clarice, que, orientada por ele, se entregou à leitura de teologia, metafísica e ética. Tardiamente, ela logrou uma resposta à telespectadora —um monólogo que ficou 5 anos em cartaz- A Alma Imoral. É o mesmo título de um livro de Bonder. Nessa peça teatral, ela conta uma anedota.

Dois advogados acompanhados com as respectivas se encontram na porta na porta do motel. Até aí... bom, mas mesmo assim, constrangimento é patente. Cada um está acompanhado da respectiva do outro. «Prezado, o certo é destrocarmos nossas acompanhantes. Não Ihe parece?». "Meu caro, a destroca pode até ser o certo, mas não é justa: afinal, você já está saindo, e eu ainda estou chegando».

Numa situação já criada, no seu aí, ajustar o certo num acontecimento ético não é uma questão de precisão. Ajustar o certo é antes uma descoberta, uma surpresa. O certo aparece preciso a partir do conceito vestido de uma destinação racional, como dever-ser. Mas o justo, que é incerto, aparece na narrativa que nos desarma e nos desata. Nem que seja num riso.

O certo traz uma demanda por definições, decisões, operações lógicas, coerências, classificações, análises, controles e previsões. Na piada, o certo é a fidelidade como obrigação matrimonial. Mas o justo se deixa escapar dessas apropriações de um mundo que se mostra aí totalizado e neutralizado. Na ética, o certo é «um» justo possível. Mas, «o» justo é o que nos convoca insistentemente na coexistência, a presença do outro que valora, mas que me escapa da totalização.

Conquanto «o» justo só tem de exato o que escapa a qualquer certeza, se insinua para nós num contar de uma anedota, uma estória, desde que se faça como aparecimento da face encarnada de alguém. Há no justo o que é impossível de ser decidido, ele é misterioso. Ele só pode ser comungado. E ele é comungado na presença daquele em que se mostra inteiro no silêncio tanto quanto no próprio dizer: uma pessoa, e não um personagem. ISSN: 1134 - 993X, Núm. 46/2012, Bilbao, págs. 107-131 
O justo é o que se (des)diz num contexto de apego e desapego, de ser atravessado tanto pela identificação como pelo estranhamento na presença do próximo. Enfim, aquilo que acontece quando tornamos o próximo mais próximo. Tão próximo que somos absorvidos, mas não anulados. Tão próximo, que esquecemos de nossa própria existência, mas existimos no próprio esquecimento que é essa absorção. Tão absortos no outro, que não sou eu nem você, mas alguém que é todos nós sem ser coletividade, além de qualquer consenso, além do que digamos ser o certo. Mas, alguém com quem convivemos mesmo que vivamos remando no Atlântico.

Posso dizer isso de uma outra maneira.

O Direito, quiçá mais do qualquer outra obra do espírito humano, pode ser percebido como um sistema de edifícios conceituais, que chamaremos de escrituras. Nessas estruturas, um conceito é sempre e inevitavelmente entendido como precedente, mais fundamental, central, original do que outros conceitos que irão gravitar em torno, ou dele derivar. Se há essa construção, então há algum tipo de arbitrariedade, ainda que sutil. Há também uma tensão entre esses conceitos que compõem o edifício, isto é, a escritura se mostra pela própria oposição entre a centralidade e a marginalidade no construto.

Se há essa tensão imanente, a perturbação desse edifício é uma possibilidade que se realiza com a própria historicidade. Poder-se-á paradoxalmente afirmar então que perturbação da ordem é uma necessidade decorrente do próprio ser construído, vestido, que é o Direito.

Com essa afirmação ontológica para o Direito, poder-se-ia conduzir ao niilismo, na medida em que afirma que tudo no direito pode se dissolver. Nada restaria senão o cinismo de fundamentar o Direito, conquanto se saberia que tal fundamento é puro mito, muralha de conservação e autopreservação que se desfaz como em Jericó — tudo que é sólido se desmancha no ar-. Aqui se mostra a importância da ética para o Direito. No contexto da desconstrução, não mais no sentido de se buscar um fundamento ético para o Direito, o que nada mais seria do que repetir o mito do Direito justo. Mas apresenta uma postura, uma atitude construtiva, que é o cuidar do outro, essa abertura ao outro.

A questão aqui é: quem é este outro? Esta é uma questão só aparentemente fácil.

É fácil dizer do outro numa relação erótica, é ou não é ? Bom, mas o outro, no sentido radical da ética, pode ser aquele que identificamos como desejável e amável ? Se fosse, a união amorosa daqueles que se querem constituiria uma unidade egoísta, isto é, fechada. Porém, nessa união, isso não ocorre, ela é aberta: no momento em que se pensa ocorrer a união, na abençoada comunhão de almas (que nada mais significa 
que o aniquilamento do outro), neste exato momento, faz-se presente o espectro do filho. É esse espectro que não permite a sociedade da solidão de dois, mas faz com que ela se abra para o cuidado, para a hospitalidade, pois esse outro ainda desconhecido, fantasmagórico (portanto totalmente outro) justamente é quem deve ser cuidado, alimentado. Enfim, é essa abertura a esse totalmente outro espectral, no amor que não é só Eros, mas também Ágape, onde dois não viram um, mas três — que inaugura a responsabilidade hospitalar que funda toda a ética-.

$\mathrm{O}$ que isso tem a ver com o direito? Tudo a ver! Pois a atitude ética pede abertura, isto é, acolhimento dos diversos discursos com os quais não nos identificamos, mas que compõem o quadro de complexidade e diversidade sobre o qual se constrói o sentido de um justo mais que possível para o direito, no sentido de que nosso próprio discurso se constitui em diálogo com outros discursos. Isso produz espontaneamente uma normatividade que também é um mínimo de contextualização e responsabilidade.

Este artigo resgata a integridade entre técnica e poética no fazer-se verdadeiro, perdida nos cânones da produção científica desde que Galileu inventou que a natureza podia ser desencantada, se visada como um livro escrito com caracteres matemáticos.

Se a Constituição é o acontecimento instituinte do Direito em uma comunidade política contemporânea, já carrega consigo um imaginário temporal partilhado. Alguém que é cidadão de um lugar, com ela se identifica. Não somente como sujeito de Direito diante de um patrimônio cultural, como também é atravessado por uma identidade narrativa fundadora do Direito com a qual se partilha, positivada em redução nos preâmbulos dos próprios textos constitucionais. De certo modo, o texto constitucional é a mitologia do Direito.

O que vem a ser cooperação na ordem constitucional? Como introdução a uma resposta possível, cito a encíclica Caritas in Veritate:

Se o amor é inteligente, sabe encontrar também os modos para agir segundo uma previdente e justa competência como significativamente indicam muitas experiências no campo do crédito cooperativo (...) (§65)

Desde já então fica evidente que reconheço a cooperação como um valor vital existente para o Direito antes mesmo de qualquer positivação e que é suportada por normas constitucionais. 
A cooperação é o valor com o qual pessoas se afetam para servirem umas às outras. Não se está aqui se referindo a um sentido hoje mais comum de prestação de serviços, como atividade de circulação de bens imateriais no mercado, mas exatamente a sua reversão, conquanto originalmente a servidão contrasta com a idéia de mercado.

É essa servidão recíproca (mútua) a suficiência, o afeto bastante, a escolha vital, livre e digna de que a cooperação diz. É essa servidão recíproca o sentido integrativo na originalidade de uma vivência que remete à nobreza, à democracia, à solidariedade e é uma resposta à febre individualista como evidencia a conciliação da doutrina social católica com a contemporaneidade, tal como expresso na encíclica Caritas in Veritate.

Mas, o imaginário propõe incessantemente intrigas singulares que desafiam e desarranjam o universal formal nomeado (sociedade cooperativa; ato cooperativo; propriedade cooperativa) como realidade (de) codificada. Há algo que escapa a todas as tentativas de análise dos negócios ou o patrimônio das cooperativas a partir de nomenclaturas ou de resultados, seja como empresa, seja como associação; seja o cooperado como dono, seja como usuário; seja o ato cooperativo representação, seja delegação; seja a propriedade cooperativa como direito real, seja ela como posse útil.

Em termos da ética pela qual se entrega a juridicidade, é de se desconfiar de toda razão (ontológica) própria, quando levada às conseqüências últimas, a totalização, sem qualquer (es)conjuração: «summum ius, summa iniura». O máximo do direito é a injúria máxima.

Daí, elucido o enigma desta fala: A cidade morria devagar é o título de um romance de André Carvalho e João Leite ambientado em São Roque de Minas como contexto da constituição de uma cooperativa de crédito: «a mão amiga da Saromcredi está em cada ação que leva São Roque ao seu alto padrão de qualidade de vida». Não apenas para ilustrar a teoria do ato cooperativo com literatura, mas para absorver-me dessas experiências de desafio, heróicas, em uma cidade moribunda.

Sem esquecer o risco da degeneração subjetivista, o extravio estético, trata-se do resgate da narrativa entre os fatos e o direito. Não exatamente como se fora estágios elementares exteriores entre si e constitutivos de um processo dialógico — descrição «neutra» do ser, e avaliação «racional» do dever-ser-. Mas, como contramundo, no qual os valores pela ação narrada resistem por encantamento à pressão das pesquisas e às manobras do consenso. 


\section{Bibliografia}

ANDRIGHI, Fátima Nancy. "A Autonomia do Direito Cooperativo». In: KRUEGER, Guilherme (coord.). Cooperativismo e o Novo Código Civil, 2. ${ }^{\text {a }}$ ed. BH: Mandamentos, 2005.

BIALOSKORSKI, Sigismundo. Aspectos econômicos das cooperativas. BH: Mandamentos, 2006.

Bulgarelul, Waldirio. Elaboração do Direito Cooperativo. SP: Atlas, 1967.

Carvalho, André; Leite, João. A cidade morria devagar. Belo Horizonte: Armazem de ideias, 2004

CunHA, Ricarlos Almagro Vitoriano. "Técnica, Liberdade e Direito». Cadernos da escola de Magistratura Regional Federal da 2. ${ }^{a}$ Região fenomenologia e direito, vol. 4, n. ${ }^{\circ} 1$ (abr/set 2011). Rio de Janeiro: TRF 2. ${ }^{a}$ Região, 2008. p. 52-53.

De Miranda, Pontes. Tratado de Direito Privado. Tomo XLIX. 3. ${ }^{a}$ ed. Rio de Janeiro: Borsoi, 1972.

DerRIDA, Jacques. Força de lei. Trad. Leyla Perrone-Moyses. São Paulo: Martins Fontes, 2007.

FrankE, Walmor. Direito das Sociedades Cooperativas. SP: Saraiva/Edusp, 1973.

—. "A influência rochdaleana na legislação cooperativista brasileira e problemas atuais». In: De Rose, Marco Túlio (org.). A interferência estatal nas cooperativas (aspectos constitucionais, tributários, administrativos e societários). Porto Alegre: Fabris, 1985.

Guimarães, Aquiles Côrtes. «Para Uma Teoria Fenomenológica do Direito», III. Cadernos da escola de Magistratura Regional Federal da 2 Região Fenomenologia e Direito, vol. 4, n. 1 (abr/set 2011). Rio de Janeiro: TRF 2. ${ }^{a}$ Região, 2008.

—. "Para uma teoria fenomenológica do Direito», IV. Cadernos da escola de Magistratura Regional Federal da 2 Região fenomenologia e direito, vol. 4, n. ${ }^{\circ} 2$ (out. 2011/mar.2012). Rio de Janeiro: TRF 2. ${ }^{a}$ Região, 2008.

-. "Direito, valor e Técnica». Cadernos da Escola da Magistratura Regional Federal da 2. ${ }^{a}$ Região: Fenomenologia e Direito: Técnica e Direito / Escola da Magistratura Regional Federal, Tribunal Regional Federal da 2. ${ }^{2}$ Região, vol. 1, n. 2 (out. 2008/mar. 2009). Rio de Janeiro: TRF 2. ${ }^{a}$ Região, 2008.

HADDOCK-Lobo, Rafael. «A justiça e o rosto do outro em Lévinas». Cadernos da Escola da Magistratura Regional Federal da 2. ${ }^{a}$ Região: Fenomenologia e Direito, vol. 3, n. ${ }^{\circ} 1$ (abr/set 2010). Rio de Janeiro: TRF 2. ${ }^{a}$ Região, 2008.

—. Para um pensamento úmido: A filosofia a partir de Jacques Derrida. Rio de Janeiro: Nau: Ed. PUC-Rio, 2011.

Hartmann, Nicolai. Ontologia, vol 1. 2. ${ }^{\text {a }}$ ed. Trad. José Gaos. Cid. Mexico: Cultura Econômica, 1965.

Heidegger, Martin. Aportes a La Filosofia. Trad. Dina V. Picotti C. Buenos Aires: Biblos, 1993.

- Sobre o Humanismo. 2. ${ }^{a}$ ed. Rio de Janeiro: Editora Tempo Brasileiro, 1995. 
KRUEGer, Guilherme. Ato cooperativo e seu adequado tratamento tributário. BH: Mandamentos, 2004.

- (coord.). Ato cooperativo e seu adequado tratamento tributário. Belo Horizonte: Mandamentos, 2004.

-; DE CONTO, Mario. «Ato cooperativo: Considerações a partir dos pressupostos da hermenêutica filosófica». KRUEGER, Guilherme (coord.). Cooperativas na ordem econômica constitucional. Belo Horizonte: Mandamentos, 2008.

Luz, F. ${ }^{\circ}$ Fabio. Teoria e Prática das Sociedades Cooperativas, 5. ${ }^{a}$ ed. RJ: Irmãos Pongetti, 1961.

MACHADO, Plínio Antônio. Comentários à Legislação do Cooperativismo. SP: Unidas, 1975.

Ost, François. Contar a Lei: As Fontes Do Imaginário Juridico. Trad. Paulo Neves. São Leopoldo: Editora Unisinos, 2004.

Reale, Miguel. Verdade e Conjetura. Rio de Janeiro: Nova Fronteira, 1983.

Ricoeur, Paul. Tempo e narrativa, tomo III. Trad. Claudia Berliner. São Paulo: Martins Fontes, 2010.

SARTRE, Jean-Paul. Esboço para uma teoria das emoções. PoA: L\&PM, 2007.

SCheleR, Max. Ética, tomo I. Trad. Hilário Rodriguez Sanz. Buenos Aires: Revista de Occidente Argentina, 1948. 